\title{
The New Hungarian Model in Hungarian Economic Science Higher Education
}

\section{Summary}

Due to the effect of historic economic events Hungary learned to react quickly and effectively since this was the only way for the country to remain at the forefront of the global competition of nations. In this continued and long-lasting preparedness, there took shape the values and requirements, such as intellectual and moral excellence and the knowledge enhancement, that are found in the country's Fundamental Law, which is at the same time the national creed. The National Bank of Hungary, too, has placed its faith in this creed, as since its establishment it has striven to represent national sovereignty. The significance, social recognition and independence of the National Bank of Hungary among the national institutions also involves responsibility and obligations for the central bank. It is evident that independence is not the central bank's objective, but its instrument that provides the possibility for it to serve the public good, benefit the whole of society and contribute to social wellbeing. The bank carries this out in such a way that it assumes a committed role in developing financial culture and awareness, and the economics and social thinking that form their foundation as well as the related system of institutions and infrastructure. This study highlights the role of educational and teaching reforms, and how attention must be paid to the knowledge connections of novelties in economic sciences that counterbalance the challenges of the globalised world economy and management organisations, and this requires a new approach and practice in Hungary. The various fields of economics satisfy a significant demand and are among the most popular fields of study chosen

Dr Zoltán ZÉman, PhD, professor, Szent István University, Faculty of Economics and Social Sciences (zeman.zoltan@gtk.szie.hu). 
in Hungarian higher education not only for working in the corporate sector, but also at an institutional level.

Journal of Economic Literature (JEL) code: A22, E58, I23

Keywords: historic economic, teaching reforms, knowledge connections, economical sciences

\section{INTRODUCTION}

Since its accession to the European Union, Hungary has been characterised by an accelerated and modern way of thinking including that the country's established financial culture keeps forming and renewing itself. There are various impulses that must be accommodated since these rapid and, above all, quality reactions determine the values that can be beacons and examples in all situations. In Hungary one of the bastions of responsibility, knowledge and independence is the National Bank of Hungary. The financial crisis of 2008 showed that, in addition to the major societal function of the financial institutions in acting at intermediaries, all the economic players require the unity of trust, accountability and transparency. The corporate social responsibility (CSR) model from the business sector can be applied to financial institutions and central banks just as it can be to economic organisations.

Considering these criteria and summing up the experience of the past few years it is clear that Europe's economic advantage lies in high-quality and competitive knowledge. Hungary is also contributing to this, for example the National Bank of Hungary is placing this constant gaining and renewal of knowledge at the focus of educational efforts. The National Bank of Hungary is deeply committed, even to the detriment of its results, to serving the public good and providing various types of support within the framework of its social responsibility programmes. In terms of short- and long-term tasks, the central bank is aimed at discovering competitive (professional) knowledge, and supporting and enhancing this knowledge both at a Hungarian and an international level, since it believes that the joint goal of citizens and the state is to achieve a good life, security, order, justice and freedom. For this reasons the central bank is striving towards an economic, legal, ethical and welfare balance which lays the foundations for joint cooperation, development, learning and trust within society.

The Hungarian central bank has set itself the especially important objective of becoming an institution able to meet the challenges of the times and, learn from the economic events of the past few decades; it will pay significant attention to providing information and to raising the standard of financial culture through the education. The essential conditions for this are a stable system of values and two key items: independence and the consequent enforcement and realisation of responsibility. These basic concepts are reflected by the Bank's Social and Responsibility Strategy which was passed in 2014 and which details the efforts, guidelines and principles through which 
the central bank intends to participate in shaping qualitative public thinking and in developing and innovating in scientific and economic life.

The National Bank of Hungary thinks in the long term in terms of its educational objectives and the strategy. Competitive knowledge and its acquisition have been important from the beginning, and through them the central bank aims to establish the foundation for conscious economic thinking and to develop and support academic activities for the very small through to adults. It pays special attention to the topic of economic education and thinking and intends to support - both professionally and materially - outstanding students, researchers and experts who carry Hungary's fame into the world with their talent and diligence and create new things in their areas of expertise. By matching this objective the National Bank of Hungary, within its Social Responsibility Strategy programme, locates and supports Hungarian experts and researchers who are active in economics and finance in order to create more intellectual works at an internationally-recognised level. This will help Hungarian researchers to better access to new economic approaches and enhance their area of research.

\section{ECONOMIC SCIENCE GAINS MOMENTUM}

The contextual cornerstone of the Bolognese system consisted of the introduction of elements of quality education, practical training and life-long learning. In the West, the objectives and principles of higher education experienced no innovation for centuries since the institutionalised system of higher education contained numerous elements that helped in establishing the designated parameters and its operation had long since discovered modern educational methods. In Hungary, the Bolognese restructuring process has not yet come close to finishing since a great deal of experience is the result of practice, and so it was particularly important to review the areas concerned and to designate the competencies that can be derived from knowledge. At an international level this issue has been a preoccupation for more than 10 years, but it has only now arrived in the fields of study of Hungarian higher education. This multi-level restructuring (The World Bank, 2009; Lentner, 2014, 2015; Lentner- Szegedi-Tatay, 2015b) or, more exactly, establishment may be especially important in the future for the dynamic and inductive relationship between knowledge, education and practice. The system of vertical and horizontal connections of the established fields of competency and their interdependencies contribute greatly towards users (in the labour market) having a better view of the output knowledge that a graduate must possess in the far-reaching system of the study of economics. The Economics Committee of the Hungarian Rectors' Conference has had the same objective. In my opinion the new system of educational requirements published in the decree brings serious and effective reform to education and greatly supports the programme of change. In future the role of educational and training reforms must be increased and, at the same time, attention must be paid to the system of academic connections of innovations in economic science that combat the challenges of the globalised world economy and economic organisation which are not unknown in West European and American prac- 
tice but that represent a new approach and way of thinking in Hungary. The fields of study of economic science satisfy serious needs, and are among the most popular in Hungarians higher education, being aimed not only at the corporate sphere but also at institutions. The number of undergraduate students is about 40-45,000 and there are about 8-9000 postgraduate students. The number of the full-time students has decreased slightly, but the fall can be felt almost everywhere and negative demographic trends may, unfortunately, bring further decreases.

As a result of what is mentioned above, the dimensions of training and employment need to be more harmonised i.e. made interactive. This is a huge task which also effects the methodology of delivering knowledge while globalisation has a significant impact on traditional educational practices and systems. The only possibility that remains for Hungary is to build an effective and interactive knowledge management through their development, because this will be the basis for competitiveness, i.e. the effectiveness and promptness of knowledge delivery. Competencies can only be acquired if the practical or dual-background basis is established with the appropriate methodology for students to come into their possession. In other words, interactive teaching programmes must be elaborated that can be realised in practice for the educational programmes operating in the current subject framework, and they must be developed at an institutional level even if this means establishing external practical departments (Lentner-Szegedi-Tatay, 2014). This may bring along the synergy that can be realised with the above-mentioned background. There are a couple of examples of a university establishing a relationship with a research institution or company, which can bring new features when this process becomes a bidirectional relationship. One of these is the department of macro-economic finance established by the National Bank of Hungary and Corvinus University in the past few months. These collaborations can enable the practical orientation of Hungarian teaching to become continuous, stronger and more responsive to demand. There are numerous foreign examples of a country's central bank supporting the country's educational system and participating in teaching: for example the Bank of England is cooperating with Warwick Business School. When elaborating the strategies of economics teaching, especially those courses providing financial teaching, the results of research demonstrating the economy's development needs can be very useful. It is worth drawing attention to the fact that in the countries where they would like to establish effective financial education or to evaluate its effects nationally, this issue receives important prioritisation at a social and economic level. Economic leaders are capable of determining the potential needs of a country's economic development and educational culture, and of mapping all the deficiencies that can be brought about by economic development decisions. For this reason, financial education strategy plays a huge role in the entire educational system (Bárczi- Zéman, 2015; Borszéki, 2010).

The support of the central bank provided through dual education is similarly successful. The objective of this programme is to create modern economic research, development and education centres, via the support of the central bank, where there can take place the establishment of a competitive database that is aligned with the 
changing needs of the labour market. Dual education was established with the Faculty of Mechanical Engineering and Automation of Kecskemét College, where students take part, within the mechanical engineering and business and mechanical engineering departments, in a high level of teaching by the standards of institutions and departments that provide an engineering degree.

Although there have been significant steps forward in the elaboration of these, methodology issues are often forgotten or not dealt with at all. In my opinion the harder a syllabus is, the more attention has to be paid to the process of delivery or acquisition of knowledge, i.e. the methodological background for difficult areas must not be forgotten. It is notable that the faster a society has developed, the bigger the need to moderate micro- and macro-economic risks that are hidden in economic-financial behaviour. Naturally, we can only be forward-looking in terms of research if there are useable results from economic science that bring solutions to problems in practice. There are programmes in post-graduate education that are accepted at international level as a good example I would mention the DProf course being organised by the National Bank of Hungary together with the accredited programme of an outstanding foreign university - and that stress transdisciplinarity, providing the opportunity to reveal the academic interdependencies of problems through a totally different academic approach. Often uncertainty is caused in the social and economic sciences regarding how multidisciplinary, interdisciplinary and trans-disciplinary issues can be harmonised in the educational (doctoral) programmes. It is also notable that in an accelerated economy these appear first as needs then as requirements, stressing again the methodology of knowledge delivery that needs to be renewed in every area including in "internationalisation". Considering all this, Hungary is not becoming valued on the international stage because of the number of foreign students, but because of the international programmes we can offer to citizens of the world. I believe that the employment of foreign guest lecturers and professors and their connection to doctoral programmes can help to a significant degree. The central bank's educational programme leads in this regard, for example, in the finding of points of linkage in geopolitical courses and international trends. It is notable that it was accepted at the Doctoral School without breaching any accreditation requirements. This is unique because, as far as I know, adaptation at such a high level (to the doctoral programme) has not taken place yet within Europe. The United States and Australia are at the leading edge in this process but we now it can be stated that there is a Hungarian example that can "mature". It is notable that this kind of activity, such as has been assumed by the National Bank of Hungary management, has developed in the Western countries (through patronage) across many centuries through the support of the civil sphere (Gábor-Bárczi, 2015). Through total chauvinism certain institutions have deprived themselves of the serious advantages and opportunities of collaboration but they will be compelled to live with this in the current institutional restructuring of the higher education. The universities of Western countries towards each other and towards taking each-other's methods and syllabuses. This is why Marketing Management by Philip Kotler, Mathematics for Economists by Sydsaeter-Hammond and Modern Corporate Finance by Brealey-Myers are used and 
accepted all over the world at every economics faculty (Lentner-Szegedi-Tatay, 2015a; $2015 b$ ). Research organised through similar collaboration (analysis and evaluation of international programmes) and doctoral programmes can new and innovative scientific results that may provide significant information to the areas of science both at the macro- and micro-economic level.

At professional forums I have stressed many times that in the future the dynamic and inductive relationship between science, education and best practice is of particular significance. Naturally this works when we increase their connectivity and the functional effectiveness between them. In this process the methodology for and effectiveness of delivering knowledge becomes important. This does not mean there is no time to teach or educate, but that the most important knowledge must be acquired quickly to a high quality. The continuous development of competency has the same objective and can still rely on the knowledge established by research.

At the same time, I would like to note that the didactic conclusions and continuous development has emerged as a new element in of knowledge management culture and methodology, as pursued by the major centres (e.g.: Oxford, Harvard, Scandinavian countries); this can supported researches through the operation of effective knowledge transfer.

What does knowledge management mean?

The management of knowledge-based processes describes a bidirectional task:

- on one hand, it focuses on the interactivity of external players (e.g. synergistic competence development serving the labour market), and within this orientation toward best practice and life-long acquisition of knowledge, i.e. learning,

- on the other hand, it is adjustment to the internal operating mechanism of faculties and academic programmes - naturally not disregarding scientific needs - which includes innovative thinking in education. The approach of the above-mentioned units - science-education-best practice-methodology-innovative political scientific thinking - may represent a significant step towards qualitative higher education. Thus we have to abandon "traditional" educational forms.

It can be concluded that one of the motivators of future knowledge enhancement will be the harmony of these units which will naturally also affect the quality of higher education. In terms of Western partner institutions where the teachers have pedagogical qualifications, there is at least one nation-wide education, methodology, and learning conference every years for the teachers. With all this considered, it is not a coincidence that Western higher education - from America to Austria - seems to be completely uniform from this perspective. Qualitative education, practice-oriented training and the principle of life-long learning prevails everywhere, and there are valid modern educational-methodological solutions such as IT support, cooperation, the teacher-student relationship, playfulness, interactivity and numerous other contemporary methods. I believe that the quality of higher education is determined by the following 5 basic components:

1. preparedness of the teachers;

2. quality of the students' knowledge; 
3. efficiency of the functioning of the education system as a system of institutions;

4. how up-to-date are the manuals, books and digital material;

5. possibility of adjusting the applied methodology - which determines the degree of speed of knowledge delivery and acquisition - according to economic and social level.

When analysing Hungarian higher education it can be stated that the development of the first three components is a huge task - through the characteristics of each institution rather vary - which is naturally not good but is still acceptable. However, the syllabuses and applied methodology are not uniform and so this is a quantitative and qualitative problem too (Czakó-Husz-Szántó, 2011; The World Bank, 2009). Attention must be drawn again to the fact that the patronage of the National Bank of Hungary is causing a historic change not only in economic education but across the entirety of Hungarian higher education. If it proves the case that there is a model in economics education for producing a modern syllabus and an applicable institutional structure that is self-financing, modern and continually innovative, then higher educational institutions specialising in other subject areas are probably also applying this practice. At the same time nobody can consider serious the criticism that the National Bank of Hungary, through its patronage, hurts institutional autonomy and freedom. New thoughts, approaches and solution must be discussed in academia and, in the end, in practice and thus in real life. Hungarian innovations have always played and keep playing an important role in the world's development, even if this is mainly the result of the isolated, individual, intellectual efforts of geniuses. In the near future, however, besides discovering geniuses - there is a need for the intellectual discoveries of the masses (even they are not geniuses) in order to make innovative developments widely known and applied. There is need for a justified, vast knowledge for the predicted radical technical and technological revolution that will encompass the whole of society. Smart tools and innovative solutions are only being used in smart and prepared societies. Those who missing the preparation will miss the development. The main task for the near future will consist of producing qualitative knowledge and its proper management, which will evidently takes place at universities. In this case the enhancement of concrete financial knowledge, educational forms supported by the government or financial institutions, and educational materials may be potential instruments for solving the situation, a task which the National Bank of Hungary has assumed and is trying to fulfil. In the Hungarian economic policy model, the central bank is trying to provide increased support not only in the harmonisation of fiscal and monetary politics but also for the above-mentioned educational issues (Lentner, 2015).

Research experience and results that show the development needs of the population or some of its segments (subgroups) can be utilised well when elaborating the strategies of financial education in terms of the entire educational system. Consequently the measuring of the level of financial culture is an important task both for society and the economy since it is conducted and managed by the members of society. The task is similar in the case of the SME sector, and so this task has an impact mechanism at macro- and micro-economic level. Attention should be drawn to the fact that, in the countries that wish to establish effective financial education or intend 
to evaluate its impact at a national level, this issue receives considerable priority both at the social and economic level. The leaders of the economy - who form the specific political strategies - are able to determine the potential needs of the national financial culture of a country or economy, as well as survey all the deficiencies in order to decide which groups of society need help the most. The results of the first evaluation of financial culture performed in a country can be considered a starting point, and they may serve as reference when elaborating financial educational programmes, during which there are often huge steps forwards but methodology issues are often forgotten or not dealt with. In my opinion the more difficult a body of knowledge, the more attention needs to be paid to the process of knowledge delivery or acquisition which can be complemented well in terms of methodology, meaning that the methodology background should not be forgotten in connection with difficult areas. Recurring surveys and the analysis of the connections between particular factors can help in determining what changes have taken place in the meantime.

\section{SUMMARY}

The role of the National Bank of Hungary in society and its future objectives should be connected to the definition of its mission. The independence and responsibility of the central bank surely represents a pillar of social wellbeing since its activity exerts a direct impact on the economic environment, on companies and on the lives of citizens. In terms of its objectives, one of the central bank's main missions consists of supporting the realisation of the professional and global social objectives that reflect authenticity, create values, strengthen the unity between society and communities, strengthen scientific thinking and, not least, support the development of talent and develop financial culture. In accordance with this thinking towards value creation and preservation, the central bank's social responsibility programmes encompass a wide range of education, research, scientific activities, financial information, culture and donation to charity, with a special emphasis on the acquisition of knowledge, on value creation and on the preservation of values.

In terms of strategic objectives related to the education and financial thinking the National Bank of Hungary:

- experts and strategic cooperation partners intend to play leading roles in the renewal of the education of economic and financial experts through the foundations established to meet the objectives aligned to the central bank's tasks,

- considers its task to develop financial culture, information distribution and financial consciousness and economic and social approaches that support this, as well as the related system of institutions and infrastructure,

- intends to encourage the renewal of the financial, economic and socio-political thinking by establishing professional workshops and by supporting economic, financial, social science and interdisciplinary education programmes of carious levels,

- supports the operation of academic and cultural journals,

- operates research, teaching, educational and trainee scholarship systems, 
- supports, as part of the Pallas Athena Public Thinking Programme, talented Hungarian researchers in creating more internationally recognised intellectual products in the areas of social science, especially economics, finance and related subjects,

- organises trainee programmes for undergraduate and master's students learning at Hungarian higher educational institutions,

- tries to establish a national and international cooperation network and build connections with the world's top universities, research centres, institutions and experts,

- intends to play a role, where possible, in creating value and in preserving national values and the intellectual and cultural heritage and in transmitting values.

Based on the above, it is evident that the central bank has chosen for a base of knowledge that always insures competitiveness and helps those who decide on continuous learning and development. The National Bank of Hungary itself conducts research and provides education while creating the conditions needed for those who really wish to learn. It is a difficult yet noble task that requires the cooperation of citizens, students and the academic world. It must be clearly seen that there is a new world order in which knowledge and, innovative thoughts represent a competitive advantage, and this has become a condition of remaining in the market. With the professional and material support provided by the National Bank of Hungary is able to create economic and academic products that place it in the first rank in Europe and the world. The Social Responsibility Strategy announced by the central bank lays down the elements of a long-term process. The objective is clear, however the conscious forming of public thinking is a multi-step, innovative, fast-reacting and timeconsuming process.

Some elements of this programme have already been realised, but in order to make qualitative and lasting change happen, a lot of time still needs to pass. It is promising that numerous Hungarian colleges, universities and doctoral schools recognised at a European and international level have cooperated with the central bank and launched successful projects such as the dual education, the National Bank of Hungary professorship or the Pallas Athena Geopolitical Doctoral Programme.

In the future projects like these are going to increase in number since in many cases only the initial steps have been made and preparatory works undertaken for cooperation. However the objective is always the same: to create knowledge and value with responsibility.

\section{REFERENCES}

Atkinson, Adele - Messy, Flore-Anne (2012): Measuring Financial Literacy. Results of the OECD / International Network on Financial Education (INFE) Pilot Study. OECD Working Papers on Finance, Insurance and Private Pensions, OECD Publishing, Paris, no. 15, http://dx.doi.org/10.1787/5k9csfs90fr4-en.

Bárczi, Judit - Zéman, Zoltán (2015): A pénzügyi kultúra és annak anomáliái [Financial culture and its anomalies]. Polgári Szemle, no. 4-6.

Borszéki, Éva (2010): Nemzetközi pénzügyek [International Financial Issues]. University notes, SZIE, Gödöllô. Béres, Dániel (2013): A pénzügyi kultúra - mi is ez valójában? [The Financial Culture - What is this Actually?] Pénzügyi Szemle online, June 20, www.penzugyiszemle.hu/vitaforum/a-penzugyi-kultura-mi-is-ez-valojaban. 


\section{Zoltán Zéman: The New Hungarian Model in Hungarian Economic Science...}

Carroll, Archie B. (1991): The Pyramid of Corporate Social Responsibility: Toward the Moral Management of Organizational Stakeholders. Business Horizons, vol. 34, no. 4, doi: 10.1016/0007-6813(91)90005-G.

Czakó, Ágnes - Husz, Ildikó - Szántó, Zoltán (eds.) (2011): Meddig nyújtózkodjunk? - A magyar háztartások és vállalkozások pénzügyi kultúrájának változása a válság idôszakában. [Where to Reach? Change of the Financial Culture of the Hungarian Households and Companies During the Crisis]. BCE Innovációs Központ Nonprofit Kft., Budapest.

Dimaggio, Paul (1994): Culture and Economy. In: The Handbook of Economic Sociology. Eds. N. J. Smelser, R. Swedberg, Princeton University Press, Princeton, 27-57.

Gábor, Ágnes - Bárczi, Judit (2015): A Magyar Nemzeti Bank felelôsségvállalási és oktatási programja [Responsibility and Educational Programme of the National Bank of Hungary]. Polgári Szemle, no. 4-6.

Hofstede, Geert - Hofstede, Gert Jan (2008): Kultúrák és szervezetek. Az elme szoftvere [Cultures and Organisations. Software of the Mind]. VHE Kft., Pécs.

Lentner, Csaba (2014): Hungary Performs Better. Chief Editor's address. Polgári Szemle, no. 1-2.

Lentner, Csaba (2015): Szemelvények a regnáló magyar közpénzügyi rendszerrôl - intézményi és nemzeti történeti háttérrel [Excerpts About the Prevailing Hungarian Public Money System - with Institutional and National Historic Background]. In: Állam - válság - pénzügyek. A pénzügyi piac szabályozásának és felügyeletének aktuális kérdései. [State - Crisis - Financial Issues. Current Issues of Regulating and Supervising the Financial Market]. Batthyány Lajos Szakkollégiumért Alapítvány, Gyôr.

Lentner, Csaba - Szegedi, Krisztina - Tatay, Tibor (2104): Társadalmi felelôsségvállalás a bankszektorban. [Social Responsibility in the Bank Sector]. In: A tudomány és a gyakorlat találkozása. Kautz Gyula Emlékkonferencia kötete [The Meeting Point of Science and Practice. Proceedings of a Commemorative Conference.]. Eds. Anikó Tompos, Lívia Mihályka Ablonczy, http://kgk.sze.hu/a-tudomany-es-a-gyakorlattalalkozasa.

Lentner, Csaba - Szegedi, Krisztina - Tatay, Tibor (2015a): A központi bankok társadalmi felelôssége. [Social Responsibility of Central Banks]. Vezetéstudomány, vol. 46, no. 9-10, 35-47.

Lentner, Csaba - Szegedi, Krisztina - Tatay, Tibor: (2015b): Társadalmi felelôsségvállalás a bankszektorban [Social Responsibility in the Bank Sector]. Pénzügyi Szemle, no. 1, 96-104.

MNB (2008): Együttmúködési megállapodás a pénzügyi kultúra fejlesztésérôl az MNB és a PSZÁF között. [Cooperation Agreement on Developing the Financial Culture (MNB and PSZÁF)]. Magyar Nemzeti Bank, Budapest.

MNB (2011): Pénzügyi kultúra alapkutatás [Financial Culture - Basic Research]. MNB-PÉNZIRÁNYTÚ-GFK, Budapest.

MNB (2014a): A Magyar Nemzeti Bank Alapokmánya. Függetlenség és felelôsség [Charter of the National Bank of Hungary. Independence and Responsibility]. Magyar Nemzeti Bank, Budapest.

MNB (2014b): Társadalmi Felelôsségvállalási Stratégia. Tudás és érték [Social Responsibility Strategy. Knowledge and Values]. Magyar Nemzeti Bank, Budapest.

Scholtens, Bert (2006): Finance as a Driver of Corporate Social Responsibility. Journal of Business Ethics, vol. 68, no. 1, 19-33, doi: 10.1007/s10551-006-9037-1.

Tzu-Kuan Chiu (2014): Putting Responsible Finance to Work for City Microfinance. Journal of Business Ethics, vol. 119, no. 2, 219-234, doi: 10.1007/s10551-013-1626-1.

The World Bank (2009): The Case for Financial Literacy in Developing Countries. Promoting Access to Finance by Empowering Consumers. The World Bank, DFID, OECD GGAP, Washington. 